\title{
La biografía literaria en el México contemporáneo
}

\section{Literary Biography in Contemporary Mexico}

\author{
Fabienne Bradu \\ (D) orcid.org/0000-0001-8653-5302 \\ Universidad Nacional Autónoma de México, México \\ Instituto de Investigaciones Filológicas \\ Centro de Estudios Literarios \\ fabbra@gmail.com
}

Resumen: Según Georges Steiner, no existe una teoría de la biografía sino tan sólo una praxis, que es la mejor manera de pensar el género y de realizarlo. Aquí repaso mi propia experiencia biográfica atendiendo tres casos distintos: 1) la biografía de un personaje sin obra como es la vida de Antonieta Rivas Mercado; 2) el retrato biográfico que exige otro tratamiento de la información recabada y otra redacción, a través de mi libro Damas de corazón, y 3) la biografía cronología de un poeta como Gonzalo Rojas, dotado de una extensa y rica obra de creación, en El volcán y el sosiego. Comento cada etapa, muestro las dificultades que presenta cada variante del género y trato de reflexionar sobre la biografía en general, pero siempre a partir de la experiencia propia.

Palabras clave: biografía; teoría; experiencia; siglos xx y xxi; México.

Abstract: According to Georges Steiner, there is no theory of biography, only praxis, which is the best way to think about the genre and engage in it. Below is a review of three different cases drawn from my own experience in biography: 1) Biographies of figures with no works, such as the life of Antonieta Rivas Mercado; 2) Biographical portraits that require another way of dealing with the information obtained and writing style, such as that found in my book Damas de corazón; 3) The chronological biography of a poet such as Gon- 
zalo Rojas, with his vast and rich creative oeuvre, exemplified in El volcán y el sosiego. I comment on each stage, demonstrate the difficulties presented by each variation of the genre and reflect on biographical writing in general, on the basis of my own experience.

Key words: biography; theory; experience, 20th Century, 21st Century; Mexico.

$\mathrm{T}$ endría que comenzar poniendo en tela de juicio el título que acabo de escribir. El adjetivo "literario" es ambiguo y, tal vez, superfluo. Si pretendo calificar el producto final, diría que toda biografía es -o debería ser- "literaria", esto es, una obra de arte con una narrativa, un ritmo y un estilo esmerados. Por lo tanto, hablar de "biografía literaria" sería una redundancia. Sin embargo, no siempre los biógrafos están conscientes de esta obligación. En particular los historiadores creen que su deber y probidad intelectual se limitan a la exactitud de la reconstrucción. Recuerdo un reclamo que, en este sentido, le hice a François Dosse en un simposio sobre la biografía organizado por el CIESAs en octubre de 2013, en la ciudad de México. Le señalaba que los historiadores suelen jalar la cobija de la biografía hacia su disciplina esgrimiendo la "cientificidad" de la historia, como si los "literatos" no fuesen capaces de llevar a cabo una escrupulosa investigación fáctica. A veces habría que pedir a los "científicos de la historia" que aprendan a escribir con elegancia y corrección los resultados de sus pesquisas. Por lo demás, el historiador francés Michel de Certeau puntualiza al respecto: "La historia no es científica, si por científica entendemos el texto que explicita las reglas de su producción. Es una mezcla, ciencia y ficción, cuyo relato no tiene más que la apariencia del razonamiento, pero no por ello está menos circunscrito a controles y posibilidades de falsificaciones" (Dosse, 2007, p. 40).

Si "la biografía literaria" se refiere a los personajes biografiados: escritores en general, entonces podemos adelantar que, en México, la tradición es escasa, parcial y relativamente reciente. En el pasado no tan remoto, pesaba sobre la biografía una desconfianza o un franco descrédito que se expresaba en términos de rechazo: al individualismo y la poca cientificidad del género. Desde los años ochenta y noventa del siglo $\mathrm{xx}$, las sospechas han ido despejándose e incluso diría que la biografía goza de cierta boga entre los lectores actuales. François Dosse (2007) lo refrenda en una página de su libro El arte de la biografía:

\section{(이) $(9$}


El carácter híbrido del género biográfico, la dificultad para clasificarlo en tal o cual disciplina organizada, la lucha entre tentaciones contradictorias, como la vocación novelesca, la preocupación erudita, la presentación de un discurso moral de la ejemplaridad, han hecho de él un subgénero que durante mucho tiempo ha sido fuente de oprobio y ha padecido de un déficit de reflexión (pp. 17-18).

Cuando en 1992 abrí en el posgrado de la Facultad de Filosofía y Letras de la Universidad Nacional Autónoma de México un seminario sobre "Biografía y autobiografía. Teoría y método", no existía ninguna materia que considerara el género como un objeto de estudio à part entière. Acuden al seminario sobre todo estudiantes que dedican un capítulo de su tesis de maestría o doctorado a la vida del escritor elegido, pero también alumnos de distintas carreras humanísticas, simplemente atraídos por el temario. Antes que despertar vocaciones, mi ambición consiste en formar lectores de biografías, otra tradición tan escasa, parcial y reciente como su producción. Saber leer una biografía es tan difícil -e imprescindible-como aprender a escribir una. A la par de los documentos y los hechos -en lenguaje científico: "los datos duros"-, importa apreciar la estructura del libro, su estilo, sus secretos o sus trampas, sus omisiones y sus logros analíticos. Virginia Woolf (1976) aseguraba que uno de los mayores desafíos de la biografía no reside en recopilar los hechos sino en contar cómo estos hechos afectaron al personaje. "Porque es muy difícil describir a un ser humano. Entonces, se dice: 'Esto es lo que sucedió'; pero sin decir a qué se parecía la persona a quien sucedieron” (p. 81). En una carta a Tomás Segovia, Octavio Paz (2008) establece una interesante distinción entre "lo pasado" y "el pasado": "Tu pasado es lo que a ti y sólo a ti te ha pasado [...] Lo pasado son los incidentes, las formas que adopta la "vida anterior', ese pasado que nunca pasa, casi siempre oculto y que sólo aparece en los días decisivos, para reordenar lo que somos y quienes somos. Lo pasado es irrecuperable pero el pasado es lo que está siempre presente" (p. 77).

La diferencia se antoja muy pertinente para recoger lo que sucede durante la elaboración de una biografía: uno tiene que reconstruir "lo pasado" para transformarlo en "el pasado" del personaje.

¿Cómo y dónde se aprende a escribir una biografía? Por desgracia y en función de mi propia experiencia, refrendaría aquí lo que les advierto a mis estudiantes al comienzo de cada semestre: no existe un manual teórico que enseñe el arte de la biografía, como tampoco existen recetarios para escribir

\section{()(1) $(9$}


una novela o un poema, pese a que algunos títulos ofrezcan semejante fraude. El mejor aprendizaje es la lectura de biografías y las experiencias narradas por los propios biógrafos. La primera fuente es bastante amplia si se aceptan las ricas tradiciones sajonas y francesas, pero, en cambio, la segunda es más limitada. Son pocos los biógrafos que han dejado un testimonio relevante de sus dudas y dificultades durante el proceso de investigación, o han sistematizado sus cavilaciones sobre el género. A mi juicio, tres autores provenientes de horizontes y tiempos diversos han reflexionado inteligentemente sobre su oficio de biógrafo: André Maurois (1935) en Aspectos de la biografía; León Edel (1990) en Vidas ajenas, principia biographica y François Dosse (2007) en El arte de la biografía. Por supuesto, abundan los artículos, académicos o no, acerca de aspectos particulares del género, pero a menudo no añaden gran cosa a lo esencial que estos tres autores han concentrado en los libros mencionados.

Un día de 1989 recibí del Fondo de Cultura Económica la propuesta de escribir una biografía de Antonieta Rivas Mercado y acepté el encargo sin tener la menor experiencia en el género. Sólo el entusiasmo compensó mi irresponsabilidad o la del editor. Por fortuna, creo no haber defraudado la confianza que la editorial depositó en mí, puesto que, desde su publicación en 1991, el libro se reimprime con una regularidad que todavía me sorprende. Me enfrentaba a la tarea de escribir la biografía de una mujer cuyo principal trofeo en la memoria o el imaginario de México, era su suicidio, en 1931, en la catedral de Notre-Dame de París. Su fin espectacular y por lo demás inédito en los anales de la catedral, acabó por borrar la empecinada construcción de una vida apasionada y adelantada a su tiempo, que intenté resumir en un epígrafe de André Gide: "Y si nuestra alma valió algo es porque ardió más fuertemente que otras." Antonieta Rivas Mercado era un mito arraigado en el imaginario de México, pero pocos conocían su decisiva parte en la creación de una cultura moderna en el país, trátese del teatro, de la música sinfónica o de la empresa editorial. Su vida vanguardista constituye lo esencial de su huella en esta tierra; carece de una obra escrita si exceptuamos un hatajo de cartas, unas intermitentes cuartillas de diario, unas páginas cedidas a José Vasconcelos sobre la campaña presidencial de 1929 y uno que otro apunte sobre temas culturales.

Ahora bien, ¿cómo estas vidas sin obra o, mejor dicho, cómo la primacía de la vida sobre la obra modifica al género biográfico? Aquí cobra un singular relieve la advertencia que hiciera Lytton Strachey (1989) a principios del siglo xx: "Es tan difícil escribir una buena vida como vivirla" (p. 24). En

\section{()(1) $(9$}


efecto, aunque él lo pensara como una regla general a toda biografía, una obediencia ineludible a la que, desgraciadamente, no se someten todos los biógrafos modernos, el mandamiento se vuelve un imponderable cuando se trata de reconstruir una vida sin la red salvadora de las obras que, por lo general, le sirven al biógrafo para no dar pasos en falso, pisar la tierra firme de lo real, aunque quiera convencernos de que allí está la vida cuando probablemente habría que buscarla en otra parte.

En su introducción al método de Leonardo da Vinci, ya Paul Valéry (1987) señalaba que semejantes manifestaciones tangibles de un individuo, como una obra, sólo corresponden a la parte visible del iceberg que es una vida y que, por ende, una biografía debería aspirar a mostrar la monstruosidad inmersa que, como sabemos, es ocho veces más grande que la parte visible. Así, según Valéry, la biografía significa "conjeturar la historia de esta graduación de la complejidad” (p. 21). Una tarea titánica y similar a la tentación de Gustave Flaubert de escribir una novela sobre nada, donde las peripecias se adelgazaran hasta tal punto que apenas sostendrían el relato. En pocas palabras, una especie de telaraña cuyo dibujo final nacería de la sutileza y la luminosidad de los hilos tramados por el biógrafo a partir de los aciertos y las errancias del personaje. Pero, a semejanza de la araña que habita su líquida arquitectura sin conocer los trazos de su perfección, nadie vive siendo, a un mismo tiempo, actor y espectador de su propia vida. ¿Cómo no recordar las palabras finales de Macbeth tratando de vislumbrar en qué consiste la vida: "Es una historia contada por un idiota, una historia llena de ruido y de furia, pero vacía de sentido"? Sólo la mirada retrospectiva del biógrafo podrá, en el mejor de los casos, sugerir la forma de la telaraña. Así, una de las mayores deslealtades hacia el biografiado no está en el artificio de la forma restituida, ni en el insensato grado de veracidad de las informaciones, ni en la cantidad de datos acumulados, sino, precisamente, en mal escribir una vida bien vivida. Es el único escollo a sortear que depende de él, porque ningún biógrafo está a salvo del error de documentación o de interpretación. Sólo los personajes de novelas tienen la seguridad de revivir eternamente el mismo destino en cada lectura: Emma Bovary siempre morirá de la misma dosis de arsénico y Ana Karenina bajo el acero del mismo tren. En este sentido, la ficción es mucho más segura que la vida. La diferencia esencial entre un personaje de novela y una persona real, asevera André Maurois (1935), reside en que el primero es creado por la inteligencia de un hombre y se vuelve así accesible a la inteligencia de otro hombre. Incluso en los casos aparentemente más mis-

\section{()(1) $(9$}


teriosos, el personaje de novela tiene una relativa y humana simplicidad. Su complejidad es ordenada. Por su parte, la autora de complejísimos personajes ficticios como Orlando o Mrs. Dalloway, sintetizaba el desafío de la biografía en la lucha entre el "granito" del hecho y el "arco iris" de la ficción.

También vale destacar la diferencia entre la biografía y la vertiente emergente de la historiografía que se llama la "historia de la vida privada". Se trata de hacer entrar en el arte de la biografía este soplo de vida, de libertad irreductible a toda obra, que a esta corriente de la historiografía no le importa recoger, porque más bien persigue cifrar en los detalles de la reconstrucción el retrato de una época. Pero Lytton Strachey (1989) también había advertido desde el nacimiento de la biografía moderna que "los seres humanos son demasiado importantes para tratarlos como meros síntomas del pasado" (p. 24). Aunque algunos lo vean como una defensa de un individualismo desenfrenado, hay que entender que el objeto y el objetivo de la biografía son distintos de los de la historia.

Ahora, del lado de la literatura, estos últimos años han registrado el auge de otra categoría neobiográfica llamada "la novela verdadera", inspirada de la tradición francesa de "le roman vrai". Su peculiaridad consiste en narrar la vida de un personaje real liberándose de la obligación de la exactitud en la reconstrucción e introducirse en la vida interior del personaje, cosa que prohíbe la biografía. Esta nueva modalidad, más literaria que histórica, puede cubrir la totalidad de una vida, pero, por lo general, suele centrarse en un tramo de vida, un episodio crucial o una relación con otro personaje histórico. En estos casos, lo que se espera es una propuesta muy personal y parcial del escritor, lejana y libre de la supuesta objetividad del biógrafo. Sin embargo, se antoja que semejante subgénero o híbrido entre la antigua novela histórica y la biografía a secas, responde a una falta de imaginación de los novelistas actuales para crear personajes inéditos. También el fenómeno coincide con otro, no menos sospechoso que la falta de imaginación, que definiría como la devaluación de la verdad en nuestras sociedades contemporáneas. Aunque sepamos que no existe la Verdad con mayúscula y prefijo absoluto, es lamentable que se renuncie a indagar la más probable verdad de unos hechos o de una vida, so pretexto que todas las variantes y variaciones son válidas. A causa de esta tendencia o deriva o desidia, se corre el riesgo de abonar y así justificar cualquier cosa sobre una persona que existió realmente. Hemos entrado en la era de las "fake news" y de la "postverdad", y quizá falte poco para que se instaure una "Historia de la difamación”, mucho más

\section{(이요 $(3$}


cruel que la borgiana infamia y totalmente impune como cualquier suerte de corrupción. Desde mucho antes del náufrago actual, André Maurois (1935) definía la biografía como "la investigación valiente de la verdad" y recomendaba al biógrafo: "Se ha de ir a la verdad con todo el alma, es decir, con toda nuestra atención, con todo nuestro respeto, con toda nuestra inteligencia, pero también con todas nuestras facultades de la intuición artística que podamos poseer" (p. 32).

Guillermo Cabrera Infante (1998) recuerda que los orígenes de la biografía se arraigan en la libre circulación de relatos que hoy reduciríamos a la categoría de "chismes", pero que la retórica ha vuelto a bautizar, con decencia, como "anécdotas". El cubano las califica, con su acostumbrada gracia, como "la proustvalía" de la historia. En las vidas sin obra, la perplejidad del biógrafo es aún mayor que la que describe Virginia Woolf (1976) cuando se disponía a escribir la vida de su amigo Roger Fry: “¿Cómo puede uno hacer una vida partiendo de seis cajas de cartón llenas de cuentas de sastres, cartas de amor y viejas tarjetas postales?" (p. 79). Cuando no existe el asidero de una obra o, cuando la vida rebasa con creces las escasas huellas abandonadas a la caprichosa posteridad, la documentación del biógrafo reside en esta "proustvalía" asistida de una parafernalia de testimonios directos o indirectos que constituyen, a un tiempo, la "máscara" del personaje y la única carne con que revestir al esqueleto de papel. Si bien en todos los casos del género, la anécdota es la carne, los músculos y, sobre todo, el nervio que animará al biografiado a vivir una segunda vida, el biógrafo de vidas sin obra se enfrentará con la ardua tarea que León Edel define como descifrar el dibujo de la alfombra y aprehender lo que se esconde debajo de la alfombra. ¿Cómo entonces pretender a un máximo de rigor cuando el dibujo de la alfombra está trazado por los turbios hilos de la "proustvalía"?

En un libro posterior, Damas de corazón (1995), dedicado a cinco mujeres mexicanas cuya vida fue su mejor obra, aventuraba el siguiente diagnóstico: Cuando publiqué la biografía de Antonieta Rivas Mercado (Bradu, 1991), comentarios de los lectores me hicieron tomar conciencia de un hecho: había completado una trilogía que, en México, se cifra en tres nombres: Frida, Tina y Antonieta. Es la trilogía de las grandes trágicas que habitan el imaginario mexicano en lo que se refiere al siglo xx y a sus mujeres. Mientras escribía Antonieta estaba yo tan obsesionada con el personaje -a quien me liga, además, la clase de amistad vicaria que se teje entre biógrafo y biografiado-, que apenas reparé en la dimensión mítica del tríptico final. ¿Había traicionado

\section{()(1) $(9$}


el propósito que animaba mi biografía: despojar a Antonieta de los velos del mito para vestirla con ropajes más verdaderos? No lo creo. Sin embargo, algo escapaba de mi control o de mi voluntad de investigadora, y no pude impedir que quienes tuvieron el libro en sus manos hicieran su propia lectura del personaje. Antonieta recobró así su envergadura mítica, pese a mi empeño por perseguir la verdad de su vida (Bradu, 1995, p. 9).

En otros términos, poco pude contra la poderosa inercia del mito y sus máscaras, por más que intenté revelar la vivacidad y el descalabro que sucedían debajo de la alfombra. México es un país sensible a las derrotas y se complace con el culto a las águilas caídas. Ahora, a la distancia, percibo la fuerza del mito que se propulsa desde la muerte hacia la vida, hacia el presente y todos nosotros. El suicidio de Antonieta Rivas Mercado nos interpela como el enigma central de su vida, porque un suicidio forma parte de la vida y todavía no pertenece a la muerte: sólo le abre la puerta, acaso aquella "puerta estrecha" de André Gide. Se dice que morir es un acto solitario, pero el suicida es aquel que camina solo hacia la muerte, con la conciencia y el deseo de que la muerte sea el único norte al cabo de sus pasos. Un suicida muere doblemente solo.

En una polémica pública con una psicoanalista (no recuerdo de qué escuela), aventuré que la superioridad de la literatura sobre el psicoanálisis se debía a la ambición de escribir lo que es imposible atestiguar. Lo mismo podría afirmarse de la filosofía, cuya limitación queda resumida en esta observación de Albert Camus: "Nunca vi a nadie morir por el argumento ontológico." No hay testigo para el suicidio; nadie puede atestiguar lo que sucede en el momento de jalar el gatillo. Por eso, escogí describir el estruendo de la detonación en el viaje de Antonieta hacia el silencio y sólo sugerir, desde la distancia, su cuerpo deslizándose sobre la madera de una banca de Notre-Dame. Este segundo en que ella apretó el gatillo de la pistola, seguirá siendo para mí su acto más insondable. Imaginar ese instante fue como parpadear cuando se pretende fijar la mirada en una escena o una persona con recrudecida atención. Y así, sólo atiné a narrar:

La detonación atronó en el silencio mortecino del mediodía. El cuerpo de Antonieta, arrebato por el impacto, comenzó a deslizarse sobre la madera bruñida. El estruendo del pistoletazo rebotaba del presbiterio al rosetón y de regreso, entre bóvedas y vitrales, trepando por las nervaduras, cayendo a

\section{()(1) $(2$}


las lozas, metiéndose a las capillas laterales y convirtiendo la cúpula en un descomunal tambor de piedras trepidantes.

El cuerpo que mostraba su corazón despedazado a los ojos de Dios cayó, con un golpe de silencio, en el centro de esa telaraña de ecos.

Después, muy lentamente, sus hilos sonoros se fueron callando y, por fin, se volvieron a quedar en paz (Bradu, 2014, p. 229).

Cuando escribí esta biografía, tenía yo un lustro más que Antonieta en el momento de su suicidio y así, mi relación con ella se parecía a la que llevan las hermanas: una mezcla de complicidad y discordias. Ahora, podría ser la madre de esta mujer prematuramente inmolada. Recuerdo el asombro de Albert Camus en El primer hombre cuando, al leer la lápida de su padre, advierte que ahora ha rebasado la edad de su progenitor, también tempranamente desaparecido en un campo de batalla. No sé si los juegos del tiempo que subvierten la cronología de los muertos y de los vivos sean relevantes, pero, sin duda, algo sucede con los trastrocamientos que se cumplen a nuestras espaldas o, como diría Javier Marías, en la "negra espalda del tiempo". Lo cierto es que la relectura de mi biografía me planteó una interrogante: ¿escribiría hoy la misma biografía?

Mi respuesta inmediata es $\mathrm{NO}$, pero me temo que daría la misma para cada uno de mis libros. No se trata exactamente de arrepentimiento sino más bien de la ilusión de poder perfeccionar lo hecho. (Tal vez también sea el síntoma de un comportamiento obsesivo y compulsivo, como suele ser el talante de muchos biógrafos.) Pero, entonces, surge otra pregunta tan contundente como la negativa anterior: ¿quién ha cambiado: Antonieta o yo? Y, en su caso, ¿qué ha cambiado? Aparentemente, la disyuntiva es un sinsentido porque los muertos no pueden cambiar. No obstante, hay que reconocerlo, los biografiados son los muertos más maleables y manoseables. Se antoja que la primera pregunta alude a la relación secreta y compleja entre biógrafo y biografiado, acerca de la cual, hasta ahora, en vano me han interrogado. León Edel (1990) advierte con sabiduría:

Lo que no comprenden [los biógrafos] -es sumamente difícil hacerlo- es que, mientras están ejecutando su tarea, su inconsciente o psique responde de más maneras que las que conocen a sus percepciones sensibles de su héroe o heroína, ese sujeto que ha demostrado ser tan atractivo (o a veces tan

\section{()(1) $\$$}


odioso) que está dispuesto a dedicar algunos años a su intento de ponerlo por escrito (p. 56).

La segunda remite a los documentos que van apareciendo o reapareciendo después de que se pone el punto final a una biografía, y modifican, completan o precisan la reconstrucción lograda. En rigor, el punto final es una expresión abusiva, meramente retórica, en el género de la biografía. Cae el punto en la página con el último aliento del personaje, mientras en la mente del biógrafo el signo se multiplica hasta formar unos puntos suspensivos que constituyen el verdadero inicio del relato: aquel que harán los lectores de la biografía. En lo sucesivo, el escritor de vidas vivirá con el desasosiego de haber clausurado un relato susceptible de crecer indefinidamente con descubrimientos documentales, pinceladas correctoras, hipótesis nuevas, mientras los lectores seguirán creyendo, erróneamente, que él ya lo sabe todo acerca de la vida del biografiado. En verdad, ni siquiera la muerte tiene el poder de cancelar y de clausurar.

No siempre pueden disociarse las dos preguntas que formulé, y voy a ilustrarlo con un ejemplo en apariencia irrelevante. Hace relativamente poco conocí la única película que subsiste, donde se ve a Antonieta Rivas Mercado actuar su mejor papel. Como la vida, dura un parpadeo. La trama coincide extrañamente con un tramo de su vida, y el título de la película podría ser: "Una tarde dominical en el campo". Antonieta viste un largo suéter claro que cae sobre una falda recta, acentuando así su elástica esbeltez, y la primera toma la muestra sentada junto a otros personajes sobre una tapia o una especie de balaustrada que cercaría una terraza de piedra. Al poco llega un automóvil, forzosamente gris en esos años del cine mudo, y los mismos personajes lo reciben a orillas del camino. Hay que mirar muy atentamente las imágenes sincopadas para ubicar a Antonieta entre otras jóvenes de su edad, acaso primas, hermanas o amigas. Antonieta se ríe e intenta taparse la boca con una mano. Ignoro a quién pertenece el automóvil y qué despierta la risa de Antonieta. Acaso alguien la interpela, le cuenta un chiste, o será que ella misma ha preparado una broma para el huésped que está llegando en el automóvil y no se aguanta la espera de su reacción. A no ser que la cámara enfocándola sea el único motivo de su retozar nervioso. Al menos, esto es lo que vagamente recuerdo de esos segundos de celuloide, pero lo que no he olvidado y vuelvo a ver con nitidez, es la risa de Antonieta.

\section{(이)(1) $(2$}


Por primera vez tuve ante mis ojos a una Antonieta en movimiento e iba a decir en carne y hueso para referirme a la inusitada corporalidad que así cobró la mujer por unos segundos. Para los biógrafos que, como yo, tienen que reconstruir la vida de un personaje carente de movilidad, de voz, de gestos en gerundio y que, al contrario, quedó cautivo de la rigidez mortuoria de los documentos, semejante espectáculo produce un escalofrío tan estremecedor como sería la aparición de su fantasma. Se recrudece la realidad de la persona o, mejor dicho, se desvanece la torpeza del personaje resurrecto mediante la puesta en palabras de una existencia. Toda la diferencia entre la vida y una biografía cabe en el trecho que separa los vocablos persona y personaje. Pero lo más asombroso de la brevísima actuación de Antonieta está en la risa que no puede reprimir ni ocultar. No solamente nunca había visto una fotografía de Antonieta riéndose sino que, debo confesarlo, tampoco la había imaginado con esa risa que descubre una hilera de dientes tan largos como escuetos eran sus labios. Dientes de marmota hambrienta y ambiciosa. Con casuística liviandad, en ese momento me pregunté si Antonieta no se reía (al menos en las fotografías) porque no le gustaba enseñar sus dientes o porque nunca tenía motivos suficientes para reírse como su suicidio parecería refrendarlo. La ausencia de una risa o de una franca sonrisa en su rostro, ¿era cuestión de vanidad o de destino? La estrambótica pregunta atestigua las obturaciones mentales de un biógrafo: es capaz de averiguar los actos y los sentimientos más íntimos de su personaje, pero resulta incapaz de conjeturar su risa. ¿Cómo pude no imaginarme la risa de Antonieta? Pero, ¿cómo se imagina una risa?

En el transcurso de la investigación sobre Antonieta Rivas Mercado, oí mencionar a otras mujeres mexicanas, narrar otras vidas selladas por la risa que despiertan la rebeldía y la libertad, y que precisamente no había sabido imaginar en la reconstrucción del trágico descalabro de Antonieta. Confieso que me irritaba la fácil asimilación entre destinos particulares y cierta imagen de la mujer mexicana, sufrida y trágica, que obnubila a nacionales y a extranjeros. Los tiempos han cambiado y la mujer mexicana tiende cada vez más a desmentir el estereotipo de la sumisión y de la resignación en el sufrimiento. Pero no se trataba únicamente de una evolución histórica y social: también en épocas pasadas existieron mujeres que no encajaban en el esquema tradicional. Recogí y escogí la vida de cinco mujeres, cuya mayor creación había sido su indomabilidad. Cada una, en distintas épocas, fue un polo en la vida cultural del país por el imán de su belleza, la gracia de sus pa-

\section{(ㅇ)(1) $(9$}


labras, la transgresión que significaba su estilo de vida, porque las animaba una casi nata curiosidad y una apuesta fundamental por la libertad. Todas vivieron de cara a la sociedad, sin otro heroísmo que el de asumir el precio de la libertad. Así, hay caídas, tropiezos o repliegues en la difícil conquista de su independencia, pero casi nunca aflora la amargura o el remordimiento. En este sentido, sus vidas fueron risueñas, ligeras y asoleadas, no exentas, sin embargo, de dolor y de complicaciones.

Damas de corazón (1995) es un conjunto de retratos biográficos, que no alcanzan la dimensión y la profundidad de la biografía clásica, pero no dejan de entrañar sus propias dificultades genéricas. Exigen casi una investigación tan demorada y detallada que la que sustenta la biografía, pero su éxito o su gracia descansa más aún en el estilo narrativo. El retrato biográfico no es tan respetuoso del tiempo como la biografía: lo acelera, lo detiene o lo desdeña en función del personaje que debe iluminarse mediante tan sólo algunas pinceladas de tiempo. Admiro la tradición francesa y española en la práctica de este subgénero, en particular a Ramón Gómez de la Serna (1988) con sus Retratos de España. No tendré la soberbia de pretender haberlo igualado, pero debo reconocer que él me provocó la tentación de ensayar esta variante de la biografía, algo bastarda, a caballo entre la historia testimonial y la literatura.

Roland Barthes condensaba aún más el retrato biográfico hasta el punto de imaginar unos "biografemas" elaborados a partir de los pequeños detalles que pueden, por sí solos, pintar por entero a un individuo, un poco al estilo de Marcel Schwob (1980) en sus Vidas imaginarias. Así expresaba Barthes su secreto deseo de posteridad: "Si yo fuera escritor, y estuviera muerto, jcómo me gustaría que mi vida se redujera, con la ayuda de un biógrafo amistoso y desenvuelto, a ciertos detalles, ciertos gustos, ciertas inflexiones, digamos 'biografemas', cuya distinción y movilidad pueden viajar fuera de cualquier destino" (Dosse, 2007, p. 307). André Breton (2000), acaso pensando en las Vidas imaginarias de Marcel Schwob, expresaba el mismo deseo:

Me gustaría que la crítica así se limitase a sabias incursiones en el dominio que más considera prohibido y que es, fuera de la obra, el campo donde la persona del autor se expresa con cabal independencia, a veces con gran singularidad, a través de los pequeños hechos de la vida cotidiana [...] ¡Cuánto me gustaría poseer de cada hombre a quien admiro un documento privado del valor de [una] anécdota! (pp. 24-25).

\section{(이요 $(3$}


En las memorias de José Vasconcelos descubrí a Consuelo Sunsín bajo el seudónimo de Charito que, más que una identidad, encubría el misterio de un destino peculiar: originaria de un pueblito de El Salvador, acabó convertida en condesa de Saint-Exupéry, después de emprender inesperados periplos y perturbar a más de un corazón de escritor. María Asúnsolo era para mí un nombre indisociable de la pintura mexicana contemporánea. Cuando visité la sala del Museo Nacional de Arte que lleva su nombre y reúne los retratos que le hicieron casi todos los miembros de la escuela moderna, me pregunté por qué ella había inspirado semejante obsesión en los pintores mexicanos de varias generaciones. Posteriormente, tuve la suerte de conocerla y de comprender que su belleza no había sido el único motivo de la asombrosa colección pictórica. La conocí en casa de la tercera retratada: Ninfa Santos, con quien me ligó una entrañable amistad hasta el día de su muerte, en julio de 1990. A lo largo de varios años visité a Ninfa Santos con asiduidad y regocijo; me fue contando su vida que revivía en cada confidencia gracias a su prodigiosa memoria y su talento narrativo. Muchas veces me sentí depositaria de historias y secretos, porque Ninfa Santos tenía el genio de la amistad y le hacía creer a cada uno de sus numerosos amigos que el relato de su vida le era destinado. Machila Armida no vivía muy lejos de la casa de Ninfa Santos en Coyoacán, y su nombre resonaba en las conversaciones de sobremesa, ligado a episodios y a otros nombres de muy diversa índole. Lo que más me incitó a indagar su vida fue la expresión de alegría que convocaba la sola mención de su nombre y la remembranza de su carácter. Quiero decir que en el transcurso de la investigación me divertí como pocas veces lo permite la tarea del biógrafo y que, al terminar la redacción del capítulo, sentí que me despedía de una amiga a quien hubiera querido conocer. Lupe Marín no necesita presentación: su figura se despliega en los muros públicos de México. Sin embargo, poco se sabía de la totalidad del personaje. Su nieta me dijo un día que era complicado aprehenderla porque había sido una mujer sencilla, elemental como los colores primarios, de una sola pieza, a la medida de su personalidad volcánica y de su deseo de ser "la única". Acepté el reto de recrear la complicada sencillez de Lupe Marín, que oscila entre la mujer terrenal y la diosa de un misterioso culto.

Una de las mayores dificultades con la que tuve que lidiar en Damas de corazón, residió en mostrar la vida íntima de estas mujeres libres y adelantadas. Por supuesto, es un brete que se plantea en toda biografía: ihasta dónde es preciso ahondar y detallar la parte íntima de una vida para, a un

\section{(ㅇ)(1) $\$$}


tiempo, decir la verdad - jtoda la verdad!-, y respetar el reducto más privado de un ser humano? La vida sexual es uno de los aspectos más trillados y compartidos por la humanidad y, por lo tanto, poco susceptible de trazar la singularidad del personaje. Prima sobre ella los sentimientos, sean estos apasionados, tibios o francamente gélidos. Por lo demás, no suele haber testigos de estos momentos de privacidad, que luego narrarían lo sucedido a un biógrafo "voyeur". El amarillismo es una tentación a evitar y otra plaga en el decálogo moral de la biografía.

A raíz de Antonieta Rivas Mercado y Damas de corazón, recibí a continuación varias propuestas para escribir las biografías de otras mujeres mexicanas. La tentación se ofrecía como una promesa de éxitos editoriales, pero advertí un peligro al cabo de semejante camino: corría yo el riesgo de convertirme en una maquiladora de biografías femeninas. Si bien no había escogido a la primera protagonista, me preciaba de poder elegir mis futuras obsesiones. Por lo demás, después de la suma de biografías femeninas que tenían en mi haber, me pregunté si sería más lioso o igualmente espinoso escribir la biografía de un hombre. En efecto, porque el biógrafo echa mano de sus propias emociones o reflexiones para comprender las de su personaje, se me antojaba aventurado abismarme en una cabeza masculina y pretender cautivar sus resortes íntimos. A priori, no tengo prejuicios en cuanto a la diferencia de sexo entre el biógrafo y el biografiado -he leído excelentes biografías marcadas por esta discordancia genérica-, y más bien dudaba de mi propia capacidad para compenetrarme con un talante masculino. Era una duda y una curiosidad que en un momento pretendí averiguar con una biografía del autor de Pedro Páramo, pero las pocas simpatías que me demuestra la Fundación Rulfo me disuadieron de ir a tocar la puerta de sus archivos. Hasta que Gonzalo Rojas irrumpió en mi horizonte intelectual y afectivo.

León Edel plantea otra pregunta crucial que ahora viene al caso recordar: "¿Quién escoge a quién?", tomando como ejemplos a Goethe y Eckermann, o a Boswell y Johnson, que fueron contemporáneos entre sí. Añade que la pregunta sigue teniendo pertinencia en el caso de personajes muertos. Para elucidarla, el biógrafo (o el lector de biografías) debe preguntarse qué rasgos del carácter o de la vida de un personaje encuentran suficientes ecos

\section{(이요 $(3$}


en la vida del biógrafo para dedicarle años de trabajo y desvelos. En otras palabras, discernir la afinidad invisible entre el biógrafo y el biografiado. Toute proportion gardée, no es soberbia mía declarar que, poco después de conocerlo, sentí que Gonzalo Rojas me indujo a volverme su biógrafa, incluso si el proyecto aparentemente provino de mi iniciativa. Ahora, con el beneficio de la distancia pero sin poder comprobarlo, diría que no hice sino someterme a un designio del poeta chileno. Desde la primera conferencia que di sobre su obra poética, en Concepción de Chile, en octubre de 1998, Gonzalo Rojas me dijo: "Siento que no es la única, ni la última vez que te ocuparás de mi obra." El vaticinio me sonó más a presunción suya que a intención mía. Sin embargo, cuando terminé la edición de su obra y la escritura de su biografía, recordé la frase vaticinadora y, entre estupefacta y divertida, no pude dejar de sonreírme en mis adentros. O bien, toda esta especulación no es sino una fantasía mía, una suerte de autoengaño destinado a crearme una falsa legitimidad intelectual, con la que a muchos biógrafos les gusta adornarse para dormir tranquilamente después de concluida la hazaña.

Aunque Freud era capaz de inventar todo tipo de ardid para disuadir a cualquier eventual biógrafo suyo, no dejó de advertir algunos riesgos verdaderos del género. Entre ellos, me importa citar este en particular: "Frecuentemente lo eligieron [al biografiado] como tema de estudio porque le tenían en seguida un afecto especial, sentimientos personales. Se entregan entonces a un trabajo de idealización que se esfuerza por inscribir al gran hombre en la serie de sus modelos infantiles, por ejemplo, hacer revivir en él la representación infantil del padre" (Dosse, 2007, p. 332).

Debo confesar que Gonzalo Rojas encarnaba para mí al padre ideal que no tuve: era un poeta sabio que me enseñaba muchas cosas sobre la literatura y la vida, y que además era cordial, divertido, atento a la manera de pensar de los jóvenes. Por lo tanto, el riesgo de idealización señalado por Freud me concierne muy particularmente. Mi salvación fue que comencé a escribir su biografía después de su muerte en abril de 2011. Así, algunos aspectos de su carácter que desconocía y fueron apareciendo hacia el final de la investigación, rectificaron por sí solos mis excesos de idealización. Me refiero sobre todo a su trato con las mujeres a quien amó y a veces maltrató en su existencia. En este caso, mi cercanía con el poeta en los últimos años de su vida, si bien me ayudó en el conocimiento de su pensamiento y su cotidianidad, enturbió la distancia necesaria entre el biógrafo y su personaje con afectos mezclados de reprobaciones y admiración.

\section{()(1) $(9$}


Unos días, durante nuestras conversaciones, Gonzalo Rojas abría irrestrictamente la llave de sus recuerdos y otras, recubría algunos episodios de su vida con el velo del mito que iba inventando en el momento. En Otras sílabas sobre Gonzalo Rojas (Bradu, 2002) una suerte de anticipo a la biografía que vino después, reproduje un cuento armado por él sobre su salida de la RDA al cabo de su primer exilio. Sólo hasta después de su muerte, supe por su hijo Rodrigo Tomás que también pasó el exilio en la RDA, cómo había sido exactamente la partida de su padre. Huelga precisar que la versión aderezada por la imaginación del poeta era mucho más atractiva que la realidad desde un punto de vista narrativo. Con el tiempo y la investigación, llegué a discernir las mitificaciones de Gonzalo Rojas y también a estar cierta de que el único ámbito en el que no mentía era la poesía. En realidad, además de comprobar que las condiciones de cada biografía difieren, cabe añadir que ninguna es preferible sobre otra. Se gana por un lado y se pierde siempre por otro, casi en la misma proporción.

La biografía de Gonzalo Rojas que me proponía escribir, se presentaba como el casi exacto revés de mi experiencia anterior: el personaje era un hombre que había dejado una obra poética considerable; su longevidad contrastaba con las tres décadas de vida de la mexicana; abundaba la documentación sobre él y su creación, entre otras disparidades. Chile era un terreno mal conocido para mí en materia de historia política, social y cultural. Tuve que investigar mucho más a fondo que en mis biografías anteriores, el contexto en que se inscribía el destino particular de mi personaje. El resultado, como luego se comentó en Chile, es que la biografía ofrece, tal un suplemento, una reconstrucción de la historia cultural del país durante casi todo el siglo xx, poco frecuente en otras publicaciones nacionales. En otros términos, a veces las carencias de un autor se vuelven unas ventajas accesorias para los lectores.

La cercanía para con el poeta contrastaba con la lejanía que me separaba de su país, de los archivos, de las bibliotecas y de los testigos directos e indirectos. Cada viaje a Chile suponía unos malabarismos para conseguir licencias, apoyos y toda una suerte de estratagemas para investigar in situ. El gobierno chileno, a través de sus instituciones culturales, se mostró invariablemente indiferente a mis solicitudes de apoyo. En cambio, la Universidad Nacional Autónoma de México, en cuyo Instituto de Investigaciones Filológicas trabajo, siempre intentó facilitarme los desplazamientos y las estancias de investigación en la medida de sus posibilidades presupuestarias, cada año más menguadas. En más de una ocasión tuve que financiarme a mí misma

\section{()(1) $\circledast$}


viajes y alojamientos. Quizá esto se considere una cuestión aledaña en estas cavilaciones sobre el género, pero estas son las condiciones prácticas del biógrafo y no dejan de influir en el resultado. Sólo una vez en mi vida escuché con embeleso y envidia el relato de la vida ideal de un biógrafo. En un viaje a México, Annie Cohen-Solal me contó cómo había sido contactada por el editor André Schiffrin para escribir la primera biografía de Jean-Paul Sartre después de su muerte. André Schriffin le ofrecía: anticipos, viajes, tiempo, encuentros con testigos claves, sus propios archivos y recuerdos, en pocas palabras, las condiciones de las que nadie dispone para investigar y escribir una biografía. El beneficio de semejantes condiciones queda a disposición del lector en Sartre (1905-1980), Gallimard, 1985, una de las dieciséis traducciones del libro inicialmente publicado en inglés, en Nueva York.

Curiosamente, al problema de la distancia geográfica se sumaba para mí la distancia cultural y lingüística entre Chile y México. De hecho, El volcán y el sosiego iría a publicarse simultáneamente en los dos países, pero ¿para qué público lector debía yo escribir? Algunas referencias políticas o culturales me parecían obvias para Chile y a lo mejor desconocidas en México. Determinados vocablos no son comunes a ambos países por más que se supone que comparten el mismo idioma. Parecen asuntos de detalles, pero sobre todo el primer punto se me planteaba con cierta frecuencia, como de todas maneras se le plantea al biógrafo en cualquier caso. ¿Hasta dónde es su obligación informar al lector del contexto en que se inserta la vida del personaje? Las notas de pie de página a menudo se convierten en una tabla de salvación para resarcir las eventuales lagunas de un hipotético lector. Sin embargo, resulta difícil determinar a priori semejantes lagunas y si bien, por lo general, un biógrafo puede suponer que se dirige a un público más o menos culto, no siempre es el caso.

Otro tipo de sorpresas reserva la recepción de una biografía en distintos contextos, para el caso, en Chile y en México. En el país sureño, la tradición biográfica es todavía más escasa que en México y hasta diría, casi inexistente. Se han publicado biografías de sesgo claramente histórico, biografías intelectuales o retratos parciales de figuras literarias, pero pocas, muy pocas biografías con todas las de la ley, que suponen una imbricación entre vida personal o privada y vida pública o creativa del personaje. Como muchos otros poetas, Gonzalo Rojas escribía poemas a partir de circunstancias concretas de vida, lo cual imposibilita la separación entre el ámbito privado y el creador. Sin embargo, algunos críticos se asombraron de ver las dos vertien-

\section{()(1) $\$$}


tes reunidas en un solo libro y así, yo me di cuenta de que la práctica no era usual en Chile. Quizá más aún que México, Chile teme la exhibición de la vida privada, aunque el "chisme" o la "copucha" sea uno de los deportes favoritos de sus habitantes. Pero resulta incongruente pretender mostrar cómo una obra surge de circunstancias de vida sin aludir a ellas, como tampoco se entendería la alquimia que se produce entre vida y poesía si no se conociera el punto de partida y el de llegada.

La longevidad del poeta y la relevancia de su obra me llevaron a redactar un manuscrito de desmesurada dimensión: más de mil páginas que, según yo, apenas daban un pálido y parcial reflejo de lo que pudo haber sido la vida de Gonzalo Rojas. La editorial me pidió reducir el manuscrito a 700 páginas, de tal manera que la biografía impresa no rebasara las 500. Esta reducción fue quizá la etapa más difícil y cruel de la aventura. Separar la paja del grano significó suprimir muchos de los "adornos" literarios debidos a mi pluma, o sea, según yo, las partes más "logradas" de la redacción. Fue un ejercicio inmejorable para castigar el ego, reflexionar sobre lo esencial y pergeñar una sobriedad sin desmérito del ritmo narrativo. Suele pensarse que lo más difícil en la biografía es la recopilación de documentos y testimonios, pero también lo es la selección del material a incluir, en el entendido de que es imposible narrar la totalidad de una vida. André Maurois (1935) afirma al respecto: "La biografía no consiste en decir todo lo que se sabe, pues entonces cualquier libro sería tan largo como una vida, sino en tener en cuenta lo que se sabe y escoger lo esencial" (p. 64).

Para terminar, quisiera añadir que todavía no veo con suficiente distancia la biografía de Gonzalo Rojas para elaborar un diagnóstico más detallado de la experiencia que apenas concluyó hace tres meses con la publicación del libro. Se necesita que pasen los años para que el biógrafo se dé cuenta de las trampas que sorteó y las otras en las que cayó, tal vez a pesar suyo. Sin embargo, me gustaría citar las palabras de Mark Schorer, el biógrafo de Sinclair Lewis, a quien menciona León Edel (1990) en su estudio mencionado. Reconozco en la confesión de Mark Schorer mucho de mi propia experiencia:

Mi larga conversación con Sinclair Lewis me enseñó mucho. Al ir aprendiendo acerca de él con toda su obstinada deficiencia en el conocimiento de sí mismo, creo que gané en conocimiento de mí mismo. No soy un hombre mejor, sin duda, por haber escrito su vida, pero pienso que soy más sabio. Sólo

\section{()(1) $(2$}


puedo esperar que mi gratitud hacia él por esto aliviará un poco la responsabilidad de la vida con que lo he agobiado (p. 61).

\section{LISTA DE REFERENCIAS}

Bradu, F. (1991). Antonieta, una biografía de Antonieta Rivas Mercado. México: Fondo de Cultura Económica (Col. Vida y Pensamiento de México).

Bradu, F. (1995). Damas de corazón. México: Fondo de Cultura Económica (Col. Vida y Pensamiento de México).

Bradu, F. (2002). Otras sílabas sobre Gonzalo Rojas. México: Fondo de Cultura Económica (Col. Tierra Firme).

Bradu, F. (2014). Antonieta (1900-1931). México: Fondo de Cultura Económica.

Bradu F. (2016). El volcán y el sosiego, una biografía de Gonzalo Rojas. México-Santiago de Chile: Fondo de Cultura Económica (Col. Tierra Firme).

Breton, A. (2000). Nadja (trad. y pról. de Fabienne Bradu). Santiago de Chile: Fondo de Cultura Económica (Colección Popular).

Cabrera Infante, G. (1998). Vida para leerlas. Madrid: Alfaguara.

Dosse, F. (2007). El arte de la biografía. México: Universidad Iberoamericana.

Edel, L. (1990). Vidas ajenas, principia biographica. Buenos Aires: Fondo de Cultura Económica.

Gómez de la Serna, R. (1988). Retratos de España. Madrid: Ediciones B.

Maurois, A. (1935). Aspectos de la biografía. Santiago de Chile: Ercilla.

Paz, O. (2008). Cartas a Tomás Segovia (1957-1985). México: Fondo de Cultura Económica (Col. Tezontle).

Schwob, M. (1980). Vidas imaginarias. Buenos Aires: Centro Editor de América Latina.

Strachey, L. (1989). Victorianos eminentes. Madrid: Aguilar.

Valéry, P. (1987). Escritos sobre Leonardo da Vinci. Madrid: Visor.

Woolf, V. (1976). Instants de vie (trad. Colette-Marie Huet; pról. Viviane Forrester). París: Stock. 